\title{
Pengaruh waktu pelapisan terhadap ketebalan dan kuat lekat pada baja karbon rendah dengan proses elektroplating
}

\author{
Nurvan Wijanarko ${ }^{1}$, Asroni $^{2^{*}}$, Eko Budiyanto ${ }^{3}$ \\ ${ }^{1}$ Prodi Teknik Mesin, Fakultas Teknik, Universitas Muhammadiyah \\ JI. Ki Hajar Dewantara 15 A Kota Metro, Lampung, Indonesia \\ 2,3Jurusan Teknik Mesin, Fakultas Teknik, Universitas Muhammadiyah Metro \\ Jl. Ki Hajar Dewantara 15 A Kota Metro, Lampung, Indonesia \\ ${ }^{*}$ Corresponding author: as.roni@aol.com
}

\begin{abstract}
Steel is a metal alloy between Iron $(F e)$ and Carbon $(C)$, where iron as the basic element and carbon as the main alloying element, electroplating is the process of coating a metal electrolytically through the use of direct electric current (DC) and chemical solutions (electrolytes). Coating aims to form a surface with different properties or dimensions from the base metal. The occurrence of deposits in the process is due to the presence of ions in the electrolyte which will settle at the cathode, this study used variations in coating time of 20 minutes, 25 minutes, and 30 minutes, then thickness and adhesive strength. The tests result were carried out. coating time 30 minutes with an average $0.314 \mathrm{~mm}$ average adhesive strength $26.79 \mathrm{MPa}$, coating time 25 minutes with an average thickness of $0.216 \mathrm{~mm}$ average adhesive strength value $22.58 \mathrm{MPa}$, coating time 20 minutes with an average thickness of $0.114 \mathrm{~mm}$ the average adhesive strength value $18.95 \mathrm{MPa}$.
\end{abstract}

Keywords: Steel, coating time, electroplating, thickness test, adhesive strength test.

\begin{abstract}
Abstrak
Baja adalah logam paduan antara besi (Fe) dan karbon (C), dimana besi sebagai unsur dasar dan karbon sebagai unsur paduan utamanya. Elektroplating atau pelapisan secara listrik merupakan proses lapisan suatu logam secara elektrolis melalui penggunaan arus listrik searah (DC) dan larutan kimia (elektrolit). Pelapisan bertujuan untuk membentuk permukaan dengan sifat atau dimensi yang berbeda dengan logam dasarnya. Terjadinya endapan pada proses disebabkan adanya ion-ion pada elektrolit tersebut akan mengendap pada katoda. Penelitian ini menggunakan variasi waktu pelapisan 20 menit, 25 menit, dan 30 menit kemudian dilakukan pengujian ketebalan dan kuat lekat. Dari pengujian yang dilakukan didapatkan hasil waktu pelapisan 30 menit dengan ketebalan rata rata $0,314 \mathrm{~mm}$ rata rata nilai kuat lekat $26,79 \mathrm{MPa}$, waktu pelapisan 25 menit dengan ketebalan rata rata $0,216 \mathrm{~mm}$ rata rata nilai kuat lekat 22,58 $\mathrm{MPa}$, waktu pelapisan 20 menit dengan ketebalan rata rata $0,114 \mathrm{~mm}$ rata rata nilai kuat lekat $18,95 \mathrm{MPa}$.

Kata kunci : Baja, waktu pelapisan, elektroplating, uji ketebalan, uji kuat lekat.
\end{abstract}

\section{Pendahuluan}

Perkembangan dan kemajuan ilmu pengetahuan serta teknologi pada industri pelapisan logam telah menjadi bidang pekerjaan yang mengalami kemajuan yang sangat pesat mulai dari jenis pelapisan, bahan pelapis yang digunakan, hingga hasil lapisannya. Tersedianya material logam yang mempunyai keunggulan sangat diperlukan untuk menjadi bahan dasar dari komponen pelapisan logam. Dalam proses pengerjaan mesin, baja merupakan salah satu logam yang paling banyak digunakan karena secara umum baja memiliki sifat yang tangguh. Namun salah satu kelemahan baja ialah dapat terkorosi secara cepat ketika 
berada di udara, lingkungan berair maupun media asam, sehingga perlu dilakukan proteksi untuk menurunkan laju korosi baja. Pelapisan logam atau plating merupakan perlindungan logam yang cukup efektif untuk mengatasi korosi [1].

Berdasarkan perlakuan permukaan suatu material logam, mekanisme interaksi akan melibatkan pertukaran ion antara perlakuan logam dengan lingkungan atau disebut dengan korosi. Korosi merupakan masalah serius dalam penggunaan bahan dari logam, karena mengakibatkan bermacam macam kerusakan, salah satu contohnya adalah berkaratnya besi. Terjadinya korosi ini berakibat penurunan mutu dan daya guna serta menimbulkan kerugian dari segi biaya perawatan. Korosi ini tidak dapat dicegah namun dapat dikendalikan. Upaya pengendalian yang lazim diterapkan dalam perlindungan terhadap logam yang digunakan adalah finishing dengan metode pelapisan pada logam [2].

Elektroplating ialah elektrodeposisi pelapis (coating) logam melekat keelektroda untuk menjaga substrat dengan memberikan permukaan dengan sifat dan dimensi berbeda dari pada logam basisnya tersebut. Beberapa proses, misalnya anodisasi chrome, elektroda yang dimaksud ialah anoda. Akan tetapi kebanyakan yang disebut elektroda dalam perumusan di atas ialah katoda [3].

Dalam proses pengerjaan logam, proses elektroplating dikategorikan sebagai proses pengerjaan akhir. Secara sederhana, dapat diartikan sebagai proses pelapisan logam, dengan menggunakan bantuan arus listrik dan senyawa kimia tertentu guna memindahkan partikel logam pelapis ke material yang hendak dilapisi. Terdapat beberapa kondisi operasi yang mempengaruhi proses elektroplating, diantaranya rapat arus, konsentrasi larutan, suhu larutan elektrolit dan lama waktu pelapisan. Karna masih perlunya informasi pengaruh elektroplating ini maka penelitian ini dimaksudkan untuk mengetahui bagaimana pengaruh suhu elektrolit dan waktu pelapisan terhadap nilai ketebalan lapisan melaui proses elektroplating [4].

\section{Tinjauan Pustaka}

Baja karbon rendah merupakan material multiguna, sedikit lebih mahal dan paling banyak diterapkan pada rekayasa material logam. Baja karbon rendah keunggulan pada sifat mekanik dan sifat fisiknya yang dapat ditingkatkan dengan proses penambahan unsur paduan dan perlakuan panas. Kekurangan dari baja karbon rendah dan paduannya adalah ketahanan terhadap korosi yang buruk meskipun bekerja dalam media korosi yang ringan, dan biasanya membutuhkan lapisan perlindungan atau pengkondisian lingkungan [5].

Prinsip dasar dari proses lapis listrik atau elektroplating adalah berdasarkan pada hukum Faraday yang menyatakan bahwa jumlah zat-zat yang terbentuk dan terbebas pada elektroda selama elektrolisis sebanding dengan jumblah arus listrik yang mengalir dalam larutan elektrolit. Disamping itu jumlah zat yang dihasilkan oleh arus listrik yang sama selama elektrolisis adalah sebanding dengan berat ekivalen masingmasing zat tersebut. Dalam pelaksanaan proses elektroplating ada beberapa hal yang perlu diperhatikan yaitu arus yang diperlukan untuk melapisi dalam proses elektroplating (rapat arus), termperatur larutan, waktu pelapisan dan konsentrasi larutan. Plating adalah salah satu cara menanggulangi korosi pada logam dan juga berfungsi sebagai ketahanan bahan, disamping itu plating juga memberikan nilai estetika pada logam yang dilapisi.

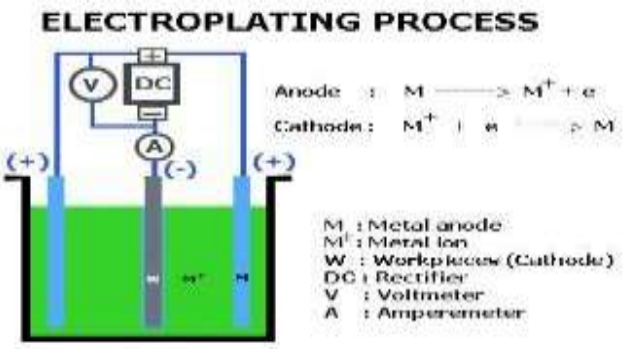

Gambar 1. Rangkaian dasar elektrik untuk elektroplating [6] 
Pada prinsipnya proses pelapisan logam dengan cara elektroplating merupakan rangkaian yang terdiri dari sumber listrik searah, anoda, katoda serta larutan elektrolit [4]. Rangkaian disusun sedemikian rupa sehingga membentuk suatu sistem lapis listrik sebagai berikut:

1. Sirkuit luar terdiri dari sumber arus DC dan peralatan terkait seperti Ampermeter, Voltmeter, dan alat pengatur tegangaan dan arus

2. Katoda adalah elektroda negative yang merupakan benda kerja yang akan dilapisi. Katoda atau benda kerja dapat memiliki bentuk dan dapat terbuat dari beraneka logam, yang terpenting katoda harus memiliki kumpulan atom-atom yang terkait dimana electron-elektronnya dapat bergerak bebas sehingga proses lapis listrik dapat berlangsung dengan baik dan logam dapat menempel kuat pada katoda

3. Di dalam larutan pelapis terdapat ion-ion logam yang sering disebut "Bath".

4. Anoda atau bahan pelapis adalah elektroda positif yang merupakan logam pelapis.Pada anoda terjadi oksidasi, ion bergerak (migrasi) ke anoda

Parameter-parameter yang

berpengaruh terhadap kualitas pelapisan Nikel adalah:

1. Konsentrasi larutan, Larutan elektrolit yaitu zat-zat yang dilarutkan dalam air murni yang dapat menjembatani partikelpartikel bermigrasi dari anoda ke katoda. Konsentrasi ini akan berkaitan dengan nilai $\mathrm{pH}$ dari larutan. Pada larutan elektrolit nikel mempunyai batas-batas $\mathrm{pH}$ yang diijinkan agar proses tersebut berlangsung baik, berkisar antara 2 4,5. Jika nilai $\mathrm{pH}$ melebihi

2. Rapat arus adalah harga yang menyatakan jumblah arus listrik yang mengalir persatuan luas permukaan elektroda.Terbagi menjadi dalam dua macam rapat arus anoda dan rapat arus katoda. Pada proses lapis listrik rapat arus yang diperhitungkan adalah rapat arus katoda, yaitu banyaknya arus listrik yang diperlukan untuk mendapatkan atom-atom logam pada tiap satuan luas permukaan benda kerja yang akan dilapisi. Untuk proses lapis listrik ini faktor rapat arus memegang peranan sangat penting, karena akan mempengaruhi efesiensi pelapisan, reaksi reduksi, oksidasi dan difusi dari hasil pelapisan pada permukaan benda yang dilapisi.

3. temperatur dan waktu pelapisan yang cukup rendah dan rapat arus yang cukup optimum akan mengakibatkan hasil pelapisan menjadi kasar dan kusam, tetapi jika temperature tinggi dengan rapat arus yang uptimum maka pelapisan menjadi tidak merata. Waktu pelapisan akan mempengaruhi terhadap kuantitas dari hasil pelapisan yang terjadi dipermukaan produk yang dilapisi. Kenaikan temperature akan menyebabkan naiknya konduktifitas dan difusitas larutan elektrolit, berarti tahanan elektrolit akan mengecil sehingga potensial akan dibutuhkan untuk meredukdi ion-ion berkurang.

Nikel adalah unsur kimia metalik dalam table periodic yang memiliki symbol $\mathrm{Ni}$, merupakan logam yang mempunyai sifat hantaran arus dan panas yang baik. Nikel digunakan sebagai pelapis dasar karena dapat menutup permukaan bahan yang dilapisi dengan baik. nikel lazim digunakan dalam berbagai aplikasi komersial dan industry.Nikel juga sangat penting dalam pembentukan logam campuran terutama baja tidak berkarat [7].

Ketebalan adalah salah satu syarat penting dari suatu lapisan hasil elektroplating.Oleh karena itu, dari sekian 
banyak jenis pengujian yang dilakukanterhadap hasil penting, permukaan ketebalan adalah salah satu uji yang harus dilakukan. Dalam merencanakan pengukuran ketebalan perlu diperhatikan kejelasan pengukuran ketebalan yang diinginkan, yaitu ketebalan rata-rata atau ketebalan pada lokasi atau titik tertentu yang sangat strategis. Diambil ketebalan rata-rata karena distribusi ketebalan yang serba sama disetiap titik pada suatu permukaan yang dilapisi jarang sekali bias dihasilkan dengan proses elektroplating.

Untuk mengetahui nilai ketebalan pada specimen maka akan dilakukan pengukuran ketebalan dengan menggunakan alat ukur veirnier caliper (jangka sorong). Ketebalan lapisan elektroplatingakan semakin tebal seiring dengan naiknya kuat arus dan juga bertambahnya distribusi arus, begitu pula dengan hasil kekerasan permukaan pada pelapisan akan bertambah kuat ketika di uji dengan menggunakan Vickers [8].

Kuat arus listrik dan Waktu proses berpengaruh terhadap Ketebalan dan Massa lapisan yang terbentuk pada proses elektroplating. Semakin besar arus listrik dan waktu proses yang digunakan, maka semakin besar pula ketebalan dan massa lapisan yang dapat terbentuk. Nilai ketebalan dan massa lapisan yang diperoleh secara teoritis lebih besar dibandingkan dengan nilai yang diperoleh dari hasil pengukuran [9].

Pengujian kelekatan pada lapisan coating dapat di uji pulloff dengan menggunakan alat posiTest AT-M Adhesion Tester, dengan spesifikasi resolusi 1 psi (0.01 Mpa), akurasi + $1 \%$ skala penuh.

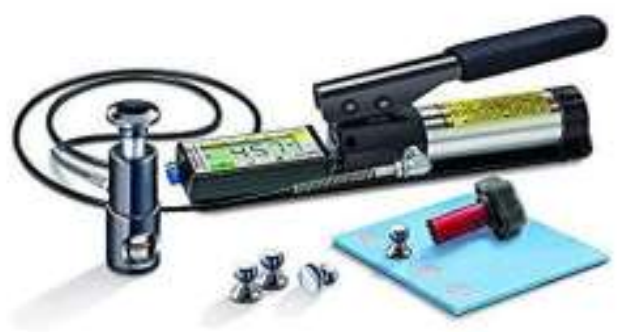

Gambar 2. Alat uji kerekatan posiTest ATM Adhesion Tester [10].

\section{Metode Penelitian}

Penelitian ini dilakukan secara langsung di laboratorium Fakultas Teknik Universitas Muhammadiyah Metro sebagai tempat proses pengerjaan elektroplating. Dalam penelitian ini menggunakan alat serta bahan untuk mendukung proses elektroplating dalam pengerjaanya. Adapun alat dan bahan yang digunakan sebagai berikut:

a) Alat Elekroplating

b) Wadah Elektroplating

c) Power Suplay

d) Multimeter

e) Penggaris

f) Stopwatch

g) Micrometer

h) Posi Test AT-M Adhesion Tester alat untuk menguji kerekatan bahan uji.

i) Baja Plat ST41 Baja karbon rendah sebagai bahan penelitian (katoda)

j) Logam Nikel sebagai bahan (anoda).

k) Nikelsulfat $\left(\mathrm{NiSO}_{4}\right)$ digunakan sebagai campuran elektrolit

1) Larutan Asam Sulfat $\left(\mathrm{H}_{2} \mathrm{SO}_{4}\right)$ digunakan sebagai larutan elektrolit

m) Kabel Kabel sebagai penghubung dan penghantar energi listrik

n) Aquades, air mineral yang telah di proses dengan cara destilasi sehinga diperoleh air murni yang bebas mineral

Dalam prosedur penelitian ini, sebelum melaksanakan penelitian terlebih dahulu mempersiapkan tahap demi tahap dalam penelitian.Adapun tahapanya sebagai berikut:

Persiapan Penelitian

Adapun persiapan penelitian sebagai berikut:

1. Wadah penampung sebagai media elektroplating

2. Bahan uji dari Logam Nikel (anoda) dan baja karbon rendah (katoda),

3. Larutan elektrolit Asam Sulfat $\left(\mathrm{H}_{2} \mathrm{SO}_{4}\right)$. 
4. Membuat bahan uji baja karbon rendah dan logam nikel lalu, memotong dengan ukuran tinggi 70 $\mathrm{mm}$, lebar $25 \mathrm{~mm}$, tebal $20 \mathrm{~mm}$.

5. Membersihkan dan menghaluskan permukaan bahan uji menggunakan gerinda, amplas dan kain lap

6. Mengukur ketebalan bahan uji gunanya untuk mengetahui sebelum pengujian dilakukan.

7. Merendam atau mencelupkan bahan uji dengan menggunakan larutan air bersih

8. Mengeringkan bahan uji dengan cara membiarkan bahan uji kering dengan sendirinya.

9. Menghubungkan baja karbon rendah (katoda) pada arus listrik negatif. Menghubungkan logam nikel (anoda) pada arus listrik positif.

Proses Pelapisan (Elektroplating)

1. Menyiapkan wadah elektrolit untuk proses elektroplating

2. Merangkai kabel-kabel yang akan dihubungkan antara katoda dan sumber daya listrik DC di sumbu positif

3. Merangkai kabel-kabel yang akan dihubungkan antara katoda dan sumber daya listrik DC di sumbu negatif

4. Menyusun sususnan katoda dan anoda sesuai ukuran yang telah diatur dalam wadah.

5. Menyiapkan larutan elektrolit $20 \mathrm{ml}$ asam sulfat (H2SO4),800 gr nikel sulfat (NiSO4) serta 2 liter Aqua Dest dan aduk hingga larutan tercampur dan merata.

6. Memasukkan elektrolit kedalam wadah sampai katoda dan anoda terendam secara baik.

7. Mengatur jarak katoda dan anoda serta tegangan listrik DC yang telah disesuaikan.

8. Menghubungkan multimeter pada saat-saat tertentu ketika ingin melakukan atau memulai proses elektroplating.
9. Melakukan pengujian ketebalan dan kerekatan pada bahan uji sebelum proses elektroplating dilakukan.

10. Menghidupkan daya listrik dan hubungkan ke power suplai ke katoda (-) dan anoda (+)

11. Mencatat waktu akan memulai perendaman dan setelah perendaman proses elektroplating saat daya listrik dihubungkan.

12. Mengangkat bahan uji pada waktu yang telah ditentukan.

13. Membersihkan bahan uji dengan menggunakan air bersih secara mengalir dan keringkan.

14. Melakukan pengujian ketebalan dan kerekatan pada bahan uji setelah proses elektroplating dilakukan.

Pengukuran Ketebalan Bahan Uji

Pengukuran ketebalan lapisan bahan uji menggunakan alat ukur micrometer.

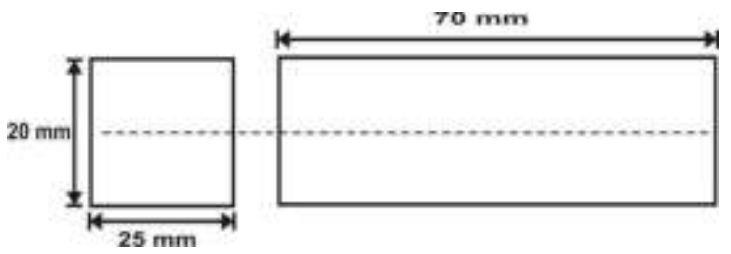

Gambar 3. Ukuran Bahan Uji.

Adapun langkah-langkah pengukuran tebal lapisan adalah sebagai berikut:

1. Mengukur ketebalan sebelum dan sesudah proses elektroplating dilakukan, bahan uji dari masingmasing sisi.

2. Setelah mendapatkan ukuran, kemudian dilakukan perhitungan perbandingan antara sebelum dan sesudah proses elektroplating. Maka akan didapat nilai ketebalan pada lapisan dari proses elektroplating

3. Mencatat hasil-hasil pengukuran yang telah dilakukan baik sebelum maupun sesudah proses pelapisan berlangsung.

4. Mengukur beberapa bahan uji dengan metode yang sama. 
Pengukuran Kuat Rekat Bahan Uji

Pengujian kerekatan lapisan hasil proses elektroplating ini dilakukan di Laboratorium Universitas Muhammadiyah Metro dengan menggunakan alat uji posi Test AT-M Adhesion Tester. Adapun langkah-langkah pengukuran kerekatan lapisan adalah sebagai berikut:

1. Benda kerja di tempelkan atau direkatkan pada bahan uji menggunakan glue atau lem poxy lalu dibiarkan mengering selama 12 jam.

2. Bersihkan bahan uji dari sisa - sisalem pada samping alat penarik dengan menggunakan alat cutting tool yang berbentuk lingkaran dan tajam.

3. Melakukan proses pengujian pull-off dengan memasukan tuas penarik kedalam alat penarik yang terhubung dengan alat indikator digital tekanan.Kemudian mulai proses penarikan sampai lapisan coating terangkat.

4. Mencatat hasil pengujian kuat rekat yang telah dilakukan.

\section{Hasil dan Pembahasan}

Pengujian yang dilakukan adalah pengujian kerekatan pada proses elektroplating yang dilakukan di Lab. Teknik Mesin Universitas Muhammadiyah Metro. Hasil pengujian yang telah didapat dimasukkan ke dalam tabel dan grafik, untuk dibandingkan dan diambil kesimpulan sehingga dapat diketahui variabel mana yang lebih optimal. Pengujian kuat lekat dan pengujian ketebalan dengan variasi waktu 20 menit dengan jumlah spesimen pengujian 3 buah, pengujian kuat lekat menggunakan alat uji tarik sedangkan pengujian ketebalan menggunakan alat jangka sorong sehingga didapatkan hasil sebagai berikut.
Tabel 1 Pengujian dengan variasi waktu 20 menit

\begin{tabular}{cccc}
\hline No & $\begin{array}{c}\text { Waktu } \\
\text { Pelapisan } \\
\text { (menit) }\end{array}$ & $\begin{array}{c}\text { Kuat } \\
\text { Lekat } \\
(\mathrm{MPa})\end{array}$ & $\begin{array}{c}\text { Ketebalan } \\
\text { Lapisan } \\
(\mathrm{mm})\end{array}$ \\
\hline 01 & 20 & 19,61 & 0,112 \\
\hline 02 & 20 & 17,65 & 0,111 \\
\hline 03 & 20 & 19,61 & 0,119 \\
\hline \multicolumn{2}{r}{ Rata- rata } & 18,95 & 0,114 \\
\hline
\end{tabular}

Pengujian kuat lekat dan pengujian ketebalan dengan variasi waktu 25 menit dengan jumlah spesimen pengujian 3 buah, pengujian kuat lekat menggunakan alat uji tarik sedangkan pengujian ketebalan menggunakan alat jangka sorong sehingga didapatkan hasil sebagai berikut:

Tabel 2. Pengujian dengan variasi waktu 25 menit

\begin{tabular}{lccc}
\hline No & $\begin{array}{c}\text { Waktu } \\
\text { Pelapisan } \\
\text { (menit) }\end{array}$ & $\begin{array}{c}\text { Kuat } \\
\text { Lekat } \\
(\mathrm{MPa})\end{array}$ & $\begin{array}{c}\text { Ketebalan } \\
\text { Lapisan } \\
(\mathrm{mm})\end{array}$ \\
\hline 01 & 25 & 22,55 & 0,208 \\
\hline 02 & 25 & 22,65 & 0,212 \\
\hline 03 & 25 & 22,55 & 0,229 \\
\hline Rata- rata & 22,58 & 22,58 \\
\hline
\end{tabular}

Pengujian kuat lekat dan pengujian ketebalan dengan variasi waktu 30 menit dengan jumlah spesimen pengujian 3 buah, pengujian kuat lekat menggunakan alat uji tarik sedangkan pengujian ketebalan menggunakan alat jangka sorong sehingga didapatkan hasil sebagai berikut.

Tabel 3 Pengujian dengan variasi waktu 30 menit

\begin{tabular}{lccc}
\hline No & $\begin{array}{c}\text { Waktu } \\
\text { Pelapisan } \\
\text { (menit) }\end{array}$ & $\begin{array}{c}\text { Kuat } \\
\text { Lekat } \\
(\mathrm{MPa})\end{array}$ & $\begin{array}{c}\text { Ketebalan } \\
\text { Lapisan } \\
(\mathrm{mm})\end{array}$ \\
\hline 01 & 30 & 27,45 & 0,312 \\
\hline 02 & 30 & 26,47 & 0,301 \\
\hline 03 & 30 & 26,47 & 0,331 \\
\hline Rata- rata & 26,79 & 0,314 \\
\hline
\end{tabular}

\section{Analisis Data}

Berdasarkan data pengujian kuat lekat dan pengujian ketebalan pada tabel di 
atas didapatkan hasil nilai rata rata dari pengujian kuat lekat dan pengujian ketebalan dari pengujian kuat lekat dan pengujian ketebalan yang telah dilakukan dengan variasi waktu 20,25, dan 30 menit dengan 9 spesimen uji didapatkan nilai rata rata sebagai berikut.

Tabel 4. Nilai rata rata pengujian kuat lekat dan ketebalan lapisan

\begin{tabular}{llll}
\hline No & $\begin{array}{l}\text { Waktu } \\
\text { Pelapisan } \\
\text { (menit) }\end{array}$ & $\begin{array}{l}\text { Kuat } \\
\text { Lekat } \\
(\mathrm{MPa})\end{array}$ & $\begin{array}{l}\text { Ketebalan } \\
\text { Lapisan } \\
(\mathrm{mm})\end{array}$ \\
\hline 01 & 20 & 18,95 & 0,114 \\
\hline 02 & 25 & 22,58 & 0,216 \\
\hline 03 & 30 & 26,79 & 0,314 \\
\hline
\end{tabular}

\section{Pembahasan}

Setelah melakukan pengujian maka dilakukan pengumpulan data yang diperoleh dari hasil pelapisan dengan memvariasikan waktu 20 menit, 25 menit, dan 35 menit. Pengujian ketebalan menggunakan jangka sorong didapatkan hasil yang mempunyai nilai ketebalan paling tinggi adalah spesimen dengan lama pelapisan 30 menit yaitu dengan rata rata nilai $0,314 \mathrm{~mm}$, sedangkan nilai ketebalan paling rendah ada pada spesimen dengan lama pelapisan 20 menit yaitu dengan nilai rata rata $0,114 \mathrm{~mm}$ dari pengujian ketebalan dengan variasi yang telah ditentukan dapat ditarik kesimpulan bahwa nilai ketebalan berbanding lurus dengan lama waktu pelapisan.

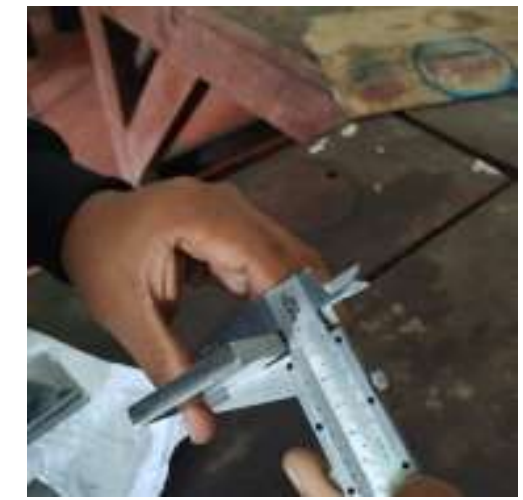

Gambar 4. Pengukuran ketebalan

Pengujian kuat lekat dilakukan menggunakan alat kuat lekat dengan memvariasikan lama waktu pelapisan 20 menit, 25 menit, dan 30 menit didapatkan hasil kekuatan lekat paling tinggi adalah spesimen dengan lama pelapisan 30 menit yaitu dengan rata rata nilai $26,79 \mathrm{MPa}$, sedangkan nilai paling rendah ada pada spesimen dengan lama pelapisan 20 menit yaitu dengan nilai $18,95 \mathrm{MPa}$. Setelah didapatkan hasil tersebut berarti dengan batasan variasi yang telah ditentukan nilai kuat lekat berbanding lurus dengan lamanya waktu pelapisan semakin lama pelapisan maka semakin tinggi nilai kuat lekatnya, berhubungan dengan penelitian yang dilakukan oleh Billy (2019) dari beberapa variasi yang telah ditentukan mendapatkan hasil nilai uji kuat lekat paling tinggi ada dilapisan elektroplating paling tebal [3]. Serta penelitian yang dilakukan oleh Dien (2019) dengan variasi waktu pelapisan 10 menit,15 menit, dan 20 menit dan didapatkan hasil nilai kuat lekat ketebalan berbanding lurus dengan lama waktu pelapisan semakin lama awaktu pelapisan semakin tinggi nilai kuat lekat dan ketebalan lapisan elektroplatingnya.

Hasil pengujian kuat lekat dengan variasi waktu pencelupan 20 menit pengujian ini mendapatkan hasil dengan nilai rata-rata kuat lekatnya $18,95 \mathrm{MPa}$ dan nilai ketebalan dengan rata rata sebesar $0,114 \mathrm{~mm}$.

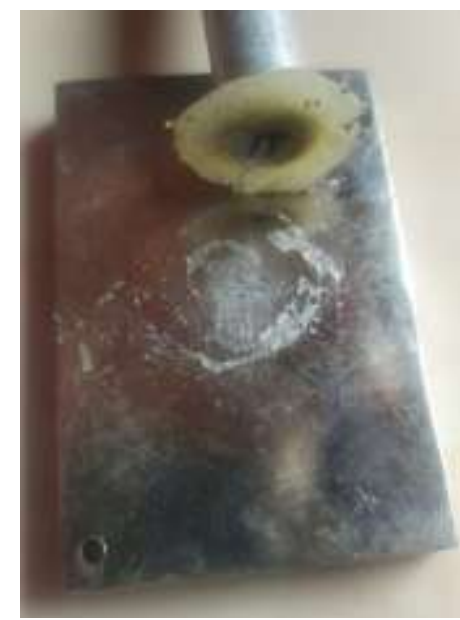

Gambar 5. Pengujian kuat lekat dengan variasi waktu pelapisan 20 menit.

Hasil pengujian kuat lekat dengan variasi waktu pencelupan 25 menit pengujian ini mendapatkan hasil dengan 
nilai rata-rata kuat lekatnya 22,58 $\mathrm{MPa}$ dan nilai ketebalan dengan rata rata sebesar $0,216 \mathrm{~mm}$ dengan lapisan elektroplating yang terangkat sebesar 15\%, hasil dari pengujian ini tidak terkelupas dikarenakan lapisan elektroplating lebih kuat dari pada lem yang digunakan.

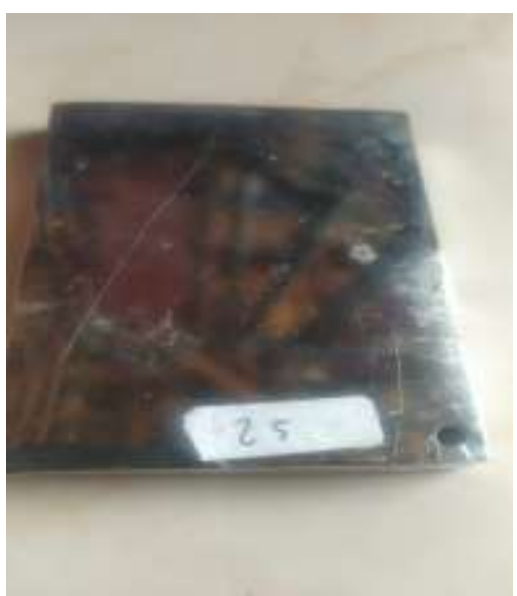

Gambar 6. Pengujian kuat lekat dengan variasi waktu pelapisan 25 menit

Hasil pengujian kuat lekat dengan variasi waktu pencelupan 25 menit pengujian ini mendapatkan hasil dengan nilai rata rata kuat lekatnya $22,58 \mathrm{MPa}$ dan nilai ketebalan dengan rata rata sebesar $0,216 \mathrm{~mm}$, hasil dari pengujian ini lapisan elektroplating pada spesimen tidak terkelupas dikarenakan lapisan elektroplating lebih kuat daripada lem yang digunakan.

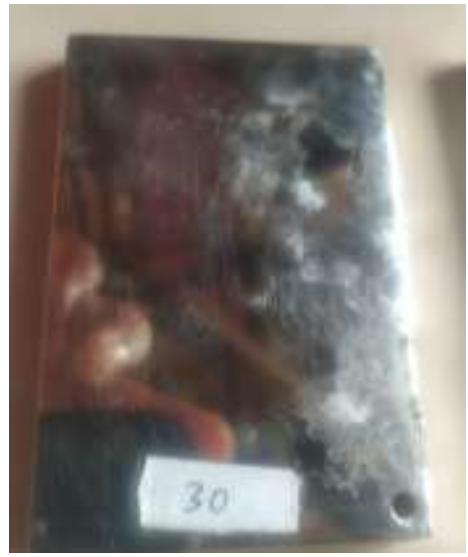

Gambar 7. Pengujian kuat lekat dengan variasi waktu pelapisan 30 menit.

\section{Kesimpulan}

Dari pengujian ketebalan didapatkan hasil, dengan waktu pelapisan 30 menit dengan rata rata nilai $0,314 \mathrm{~mm}$, waktu pelapisan 25 menit yaitu dengan nilai rata rata $0,216 \mathrm{~mm}$, dan waktu pelapisan 20 menit yaitu dengan nilai rata rata $0,114 \mathrm{~mm}$ dari hasil tersebut disimpulkan bahwa waktu celup paling optimal yaitu 30 menit dengan rata rata nilai ketebalan $0,314 \mathrm{~mm}$.

Dari pengujian tarik yang dilakukan didapatkan hasil waktu pelapisan 30 menit dengan ketebalan rata-rata $0,314 \mathrm{~mm}$ rata rata nilai kuat lekat $26,79 \mathrm{MPa}$, waktu pelapisan 25 menit dengan ketebalan rata rata $0,216 \mathrm{~mm}$ rata-rata nilai kuat lekat 22,58 $\mathrm{MPa}$, waktu pelapisan 20 menit dengan ketebalan rata-rata $0,114 \mathrm{~mm}$ rata rata-nilai kuat lekat 18,95 $\mathrm{MPa}$. Dari hasil tersebut dapat disimpulkan bahwa dengan batasan variasi yang telah ditentukan nilai kuat lekat berbanding lurus dengan lamanya waktu pelapisan semakin lama pelapisan maka semakin tinggi nilai kuat lekatnya.

\section{Referensi}

[1] Syam, F. R. (2014). Pengaruh Variasi Waktu Celup 4, 6 Dan 8 Detik Terhadap Tebal Lapisan Dan Kekasaran Tembaga Pada Pelat Baja Karbon Sedang Dengan Proses Elektroplating (Doctoral dissertation, Universitas Muhammadiyah Surakarta).

[2] Budiyanto, E., Setiawan, D. A., Supriadi, H., \& Ridhuan, K. (2017). Pengaruh jarak anoda-katoda pada proses elektroplating tembaga terhadap ketebalan lapisan dan efisiensi katoda baja AISI 1020. Turbo: Jurnal Program Studi Teknik Mesin, 5(1).

[3] Permadi, B., Asroni, A., \& Budiyanto, E. (2019). Proses elektroplating nikel dengan variasi jarak anoda katoda dan tegangan listrik pada baja ST-41.

[4] Basmal, B., Bayuseno, A. P., \& Nugroho, S. (2012). Pengaruh Suhu dan Waktu Pelapisan Tembaga-Nikel 
pada Baja Karbon Rendah Secara Elektroplating Terhadap Nilai Ketebalan dan Kekasaran.

[5] Furqon, N. G., \& Sulistijono, S. (2015). Pengaruh Densitas Arus dan Waktu Kontak Efektif Elektrolit Gel Terhadap Ketebalan Dan Kekuatan Lekat Lapisan Krom Pada Baja Dengan Metode Elektroplating.

[6] Sutomo, Senen, Rahmat, 2010. Pengaruh Arus Dan Waktu Pada Pelapisan Nikel Dengan Elektroplating Untuk Bentuk Plat. Program Diploma III Teknik Mesin, Vol. 6 No. 02. 2010 Fakultas Teknik Universitas Diponegoro.

[7] Suarsana, I Ketut 2008, Pengaruh Waktu Pelapisan Nikel Pada Tembaga Dalam Pelapisan Khrom Dekoratif Terhadap Tingkat Kecerahan Dan Ketebalan Lapisan, Jurnal Teknik Mesin CAKRAM Vol.2 No.1.Juni 2008 (48-60), Universitas Udayana, Kampus Bukit Jimbaran Bali

[8] Rasyad, Abdul, and Budiarto Budiarto. "Analisis Pengaruh Temperatur, Waktu, dan Kuat Arus Proses Elektroplating terhadap Kekuatan Tarik, Kekuatan Tekuk dan Kekerasan pada Baja Karbon Rendah." Rekayasa Mesin 9.3 (2019): 173-182.

[9] Dermawan, Arif Surya dkk, 2015, Pengaruh Variasi Kuat Arus Listrik Dan Waktu Proses Elektroplating Terhadap Kekuatan Tarik, Kekerasan Dan Ketebalan Lapisan Pada Baja Karbon Rendah Dengan Krom, Dinamika Teknik Mesin, Volume 5 No. 2 Juli 2015, Teknik Mesin Fakultas Teknik Universitas Mataram..

[10] Paridawati, 2013. Analisa Besar Pengaryh Tegangan Listrik Terhadap Ketebalan Pelapisan Chrome Pada Pelat Baja Dengan Proses Elektroplating, Jurnal Ilmiah Teknik Mesin, Vol.1, No.1 Februari 2013 Universitas Islam 45, Bekasi. 